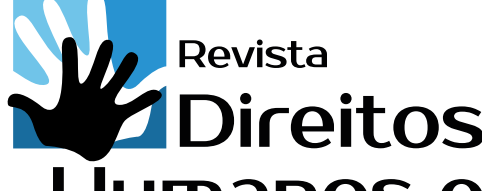 Humanos e Democracia
}

Programa de Pós-Graduação Stricto Sensu em Direito da Unijuí https://www.revistas.unijui.edu.br/index.php/direitoshumanosedemocracia

\section{Direitos Humanos e Educação: Diretrizes Fundamentais}

\section{José Irivaldo Alves Oliveira Silva}

Pós-Doutorado em Desenvolvimento Regional. Doutorado em Ciências Sociais. Doutorando em Direito e Desenvolvimento. Pesquisador Produtividade do CNPq, nível 2. Em estágio Pós-Doutoral no Programa de Pós-Graduação em Direito, no Grupo de Pesquisa em Direito Ambiental e Sociedade de Risco (Universidade Federal de Santa Catarina). Mestrado em Sociologia. Especialização em Gestão das Organizações Públicas e em Direito Empresarial. Graduação em Ciências Jurídicas. Professor efetivo do curso de Gestão Pública, na Unidade Acadêmica de Gestão Pública da Universidade Federal de Campina Grande. É pesquisador com ênfase em conflitos ambientais, meio ambiente, sociedade de risco, legislação ambiental, desenvolvimento sustentável, políticas públicas relacionadas ao acesso à água e saneamento. É membro da rede de pesquisa Waterlat (http://www.waterlat.org/Members.html\#brazil). Pesquisador da Rede Just-Side (Programa Iberoamericano de Ciencia y Tecnología). Membro da Associação Latino Americana de Sociologia (Alas). http://orcid.org/0000-0002-0022-3090.irivaldo.cdsa@gmail.com/prof.irivaldo@ufcg.edu.br

\section{Gutyelson Henrik Firmino Nunes}

Licenciatura em Educação do Campo. rykelson@gmail.com

\section{RESUMO}

O presente trabalho parte dos pressupostos traçados no Plano Nacional de Educação em Direitos Humanos (PNE$\mathrm{DH})$, e tem a preocupação de conhecer como está sendo abordada a temática dos Direitos Humanos em sala de aula. Como os professores adquirem informações sobre a temática? Quais os conhecimentos e práticas dos professores sobre o assunto? Esta temática, de acordo com o Programa mundial para educação em Direitos Humanos, é uma temática que deve permear a prática pedagógica dos professores em sala de aula. A pesquisa foi do tipo qualitativa e de natureza descritiva; o mesmo ainda se caracterizou como um estudo de caso. Num primeiro momento foi realizada uma pesquisa bibliográfica em livros e artigos, como também em sites, sobre os seguintes temas: Direitos Humanos e Educação em Direitos Humanos. Já no segundo momento foram aplicados os instrumentos de coleta de dados por meio de questionários. Dessa forma, verificou-se que a escola trabalha, de modo muito superficial, temas relacionados com os direitos humanos, a ponto de não ser percebido, ficando evidente a necessidade de avançar no sentido de fazer uma ampla discussão com a comunidade escolar sobre Direitos Humanos.

Palavras-chave: Educação do campo. Cidadania. Direitos humanos.

\section{HUMAN RIGHTS AND EDUCATION: FUNDAMENTAL GUIDELINES}

\section{ABSTRACT}

The present work is based on the assumptions established in the national human rights education (PNEDH), and is concerned to know how the subject of human rights in the classroom is being addressed. How do teachers get information on the subject? What are the teachers' knowledge and practices on the subject? This theme, according to the World Program for Human Rights Education, is a theme that must permeate the pedagogical practice of teachers in the classroom. The research was qualitative and of descriptive nature, the same was still characterized as a case study. At first, a bibliographical research of books and articles was carried out, as well as in sites of the following subjects: Human Rights and Education in Human Rights. In the second moment the instruments of data collection were applied through questionnaires. In this way, it was verified that the school works in a very superficial way subjects related to the human rights to the point of not being perceived, being evident the need to advance in the direction to make a wide discussion with the school community on Human Rights.

Keywords: Field education. Citizenship. Human rights.

\section{SUMÁRIO}

1 Introdução. 2 Contexto histórico dos direitos humanos. 3 A educação em direitos humanos na educação básica na perspectiva do Plano Nacional de Educação em Direitos Humanos. 3.1 Resgatando o Plano Nacional de Educação em Direitos Humanos (PNEDH). 3.2 A educação básica na perspectiva do PNEDH e o papel da escola. 4 Educação em direitos humanos numa escola do campo. 5 Considerações finais. 6 Referências. 


\section{INTRODUÇÃO}

A discussão que se trava no decurso do trabalho tem a intenção de saber como as temáticas de direitos humanos estão sendo inseridas no cotidiano da educação. Falar em direitos humanos é, consequentemente, lembrar-se das barbáries históricas ocorrida no mundo, que desrespeitam a dignidade da pessoa humana.

Além de um saldo de mortes muito elevado, a Guerra deixou a necessidade e o anseio do respeito à pessoa humana, ou seja, o desejo de que se fosse respeitado o direito à vida. Para que nunca mais a humanidade revivesse os fatos tão aterrorizantes contra os seres humanos, é iniciado, em conjunto com chefes de nações, uma proposta de um tratado mundial que fosse respeitado por todos. É nesse momento que tem início a ideia universal dos direitos humanos, que, por mais redundante que pareça ser, são direitos que possuímos pelo simples fato de existirmos.

Mesmo com todo histórico de violação dos direitos humanos deixado pela Segunda Guerra Mundial, bem como de outros momentos da história, é absurdo viver em pleno século 21 em uma sociedade em que ainda o desrespeito à condição humana é uma atitude comum, com rotulações de modo sutil ou explícito, com preconceitos odiosos, e que por vezes tornam-se comuns. Cabe questionar aqui o que fazer para minimizar essas ações desrespeitosas. Um caminho seria a educação escolar voltada para a formação cidadã da pessoa civilizada a partir do referencial dos Direitos Humanos.

O presente trabalho tem a preocupação de conhecer como está sendo trabalhada a temática dos Direitos Humanos em sala de aula. Como os professores adquirem informações sobre a temática? Quais os conhecimento e práticas dos professores sobre o assunto? Esta temática, de acordo com o Programa Mundial para Educação em Direitos Humanos, é uma temática que deve permear a prática pedagógica dos professores em sala de aula.

Neste sentido, objetivou-se verificar como está sendo trabalhada a temática dos Direitos Humanos no cenário das escolas do campo, focando a Escola Estadual Juarez Maracajá, no município de Gurjão, localizada na região do Cariri paraibano. De forma mais específica, procurou-se compreender o processo de desenvolvimento dos Direitos Humanos no contexto escolar, bem como verificou-se como os docentes adquiriram esses conhecimentos. Além disso, buscou-se ainda identificar como os docentes trabalharam a temática dos Direitos Humanos em sala de aula. Procurou-se, também, identificar qual a compreensão dos docentes e dos alunos sobre os Direitos Humanos.

Esta pesquisa, desenvolvida na Escola Juarez Maracajá, em Gurjão - PB -, possui caráter tipicamente qualitativo e de natureza descritiva. A mesma caracteriza-se como estudo de caso, verificada a discussão sobre os Direitos Humanos e os temas transversais relacionados. Em um primeiro momento foi realizada uma pesquisa bibliográfica de livros e artigos, como também em sites sobre os seguintes temas: Direitos Humanos e Educação em Direitos Humanos. No segundo momento foram aplicados os instrumentos de coleta de dados (o questionário). Pela técnica de aplicação de questionários foram sendo conseguidos os resultados descritos. 
O texto foi produzido em quatro sessões. A primeira trata, em linhas gerais, de uma inclusão do leitor em uma breve contextualização histórica sobre os direitos humanos. $\mathrm{Na}$ segunda tratou-se a respeito do que é a Educação em Direitos Humanos no contexto histórico do Plano Nacional de Educação em Direitos Humanos (PNEDH), debatendo, ainda, a Educação em Direitos Humanos (EDH) na educação básica, a partir do PNEDH e do papel da escola em sua disseminação. Na terceira sessão fez-se uma discussão sobre as perspectivas da Educação do Campo quanto aos direitos humanos. Na quarta e última seção apresentou-se a pesquisa de campo, expondo a metodologia e os dados do campo.

\section{CONTEXTO HISTÓRICO DOS DIREITOS HUMANOS}

Salienta-se que, em sua origem, a expressão "direitos humanos" foi chamada, em outro momento da história, de "Direitos do Homem". Essa expressão, contudo, foi alvo de críticas por causa da palavra "homem", pois a mesma dava a entender que os direitos estavam garantidos apenas para as pessoas do sexo masculino. Conforme Bellinho (2012),

A primeira nomenclatura que surgiu foi a dos direitos do homem, a qual remonta à época do jusnaturalismo, pois bastava ser homem para possuir direitos e poder usufruí-los. Entretanto, tal nomenclatura sofreu várias críticas devido à expressão "homem", tendo em vista que tais direitos não eram apenas inerentes às pessoas do sexo masculino, mas, sim, a qualquer pessoa humana (p. 2).

Assim, tendo em vista que os direitos são destinados a qualquer pessoa humana, a expressão "direito do homem", ao ser alvo de diversas críticas, foi alterado, passando, segundo Bellinho (2012), a se chamar direitos fundamentais. Claro que essa mudança marca simbolicamente a transição de compreensões acerca dos direitos, e o desafio maior estava posto: tornar os mesmos efetivos na sociedade. A ideia dos Direitos Humanos (DH), porém, tal como se conhece hoje, é relativamente nova.

Para Celso Lafer (1998), os direitos humanos se originaram das tradições judaico-cristãs e históricas da civilização ocidental, e tinha a dignidade do ser humano como fonte de valor, seja por ter sido criado à imagem e semelhança de Deus, seja por ser cidadão. Tonet (2002, p. 63) salienta, contudo, ainda, que os chamados direitos humanos foram proclamados, pela primeira vez, nas constituições dos Estados Unidos e da França, entre 1776 e 1778. De acordo com Schuler (2008), entretanto, os direitos humanos, tal como se conhece hoje, surgem a partir das grandes revoluções burguesas e da formação da sociedade moderna por meio de narrativas históricas produzidas por diversos intelectuais franceses do século 18:

Os direitos humanos surgem como narrativa histórica produzida por diversos intelectuais franceses no século XVIII, dentre eles Espinoza, Locke, Montesquieu, Rousseau, época em que eclodem as grandes revoluções burguesas. Os direitos humanos foram construídos na formação da sociedade moderna, no contexto da Revolução Francesa, da Revolução Industrial, cujas conquistas imprimiram uma nova visão dos direitos do indivíduo e do cidadão, culminando com a Declaração Universal dos Direitos Humanos (1948), promulgada pela Organização das Nações Unidas. Nascem não só para evitar atrocidades, mas para a promoção da paz (p. 143). 
Foi no cenário do século 20, a partir das atrocidades e dos horrores cometidos durante a Primeira e a Segunda Guerra Mundial e do Nazismo, todavia, que se desenhou a necessidade de criar um mecanismo que defendesse a condição humana. Regimes totalitários propagam um modelo de Estado em que há uma ausência de limites da autoridade do mesmo, sem respeitar os direitos individuais necessários para a existência humana. Como salienta Fábio Konder Comparato (2010):

[...] após três lustros de massacres e atrocidades de toda sorte, iniciados com o fortalecimento do totalitarismo estatal nos anos 30 , a humanidade compreendeu, mais do que em qualquer outra época da história, o valor supremo da dignidade humana. $O$ sofrimento como matriz da compreensão do mundo e dos homens, segundo a lição luminosa da sabedoria grega, veio a aprofundar a afirmação histórica dos direitos humanos (p. 68-69).

Foi diante dessas barbaridades, na busca de consolidar os direitos humanos, que, em 10 de dezembro de 1948, é aprovada a Declaração Universal dos Direitos Humanos (DUDH). Como marco maior do processo de reconstrução dos direitos humanos, começou a desenvolver-se o Direito Internacional dos Direitos Humanos, mediante a adoção de inúmeros tratados internacionais voltados à proteção de direitos fundamentais (PIOVESAN, 2005). Segundo Piovesan (2009),

Para Joaquín Herrera Flores os direitos humanos compõem a nossa racionalidade e resistência, traduzindo esses processos que abrem e consolidam espaço de luta pela dignidade humana, invocando uma plataforma emancipatória voltada de um lado à proteção à dignidade humana e por outro à prevenção ao sofrimento humano. Não apresentam uma história linear. Não são a história de uma marcha triunfal nem tampouco são a história de uma causa perdida de antemão, mas a constante na luta pela afirmação dos direitos humanos é serem a história de um combate, de uma luta e de ações sociais (p. 107).

Assim sendo, e de acordo com Piovesan (2009), a história dos direitos humanos até os dias de hoje deve ser vista como um espaço de luta em prol da dignidade e de combate ao sofrimento humano, uma vez que os direitos humanos são frutos do nosso passado a partir da luta e da ação social.

No caso do Brasil, vale salientar que a temática dos direitos humanos adquiriu uma elevada significação histórica também como resposta às formas de violência social e políticas vivenciadas nas décadas de 60 e 70, marcadas pelo Golpe Militar de 1964. Somente a partir dos anos 80 e 90, no entanto, o debate sobre os direitos humanos e a formação para a cidadania vem alcançando mais espaço e relevância no Brasil. Como afirma Sader (2007):

O tema dos direitos humanos não estava incluído, como tal, na agenda de discursos e de debates antes do golpe militar de 1964. Os modelos de desenvolvimento, suas conseqëências sociais, a inserção internacional do país - ocupavam grande parte das formulações teóricas e políticas. Até mesmo um conceito, como o de direito ficava relegado ao plano do direito, como se tivesse apenas uma dimensão jurídica (p. 75).

Assim, é de fundamental importância ressaltar que somente no final da década de 80 é que o tema dos direitos humanos passa a ter maior visibilidade no Brasil. De acordo com o Caderno de Educação em Direitos Humanos (CEDH), foi a Constituição Brasileira de 1988 que: 
[...] institucionalizou os direitos humanos no país, destacando a cidadania e a dignidade da pessoa humana como princípios fundamentais do Estado Brasileiro. O que é preconizado, entretanto, não se concretiza plenamente (BRASIL, 2013b, p. 21).

O questionamento que se deve enfatizar é o seguinte: Por que esses direitos não se concretizaram plenamente? Como é possível reivindicar um direito se grande parte da população não tem conhecimento de tal direito? É a partir desses questionamentos que se verifica o papel fundamental da educação como formadora e disseminadora desses direitos. A educação pode influenciar na tomada de consciência. Ainda, de acordo com Piovesan (2012):

A Constituição Brasileira de 1988 constitui o marco jurídico de transição democrática e da institucionalização dos direitos humanos no Brasil. O texto de 1988, ao simbolizar a ruptura com o regime autoritário, empresta aos direitos e garantias ênfase extraordinária, situando-se como o documento mais avançado, abrangente e pormenorizado sobre a matéria, na história constitucional do país (p. 94).

Neste sentido, é possível resgatar na história dois passos de fundamental importância para a afirmação dos Direitos Humanos (DH) no Brasil. O primeiro foi a elaboração da Constituição Federal brasileira de 1988, considerada como a "Constituição Cidadã", e que assumiu um papel preponderante na institucionalização dos direitos humanos em todo o país. O segundo foi a criação da Secretaria de Direitos Humanos da Presidência da República (SEDH). A SEDH foi criada pelo então presidente Fernando Henrique Cardoso (FHC), datada de 17 de abril de 1997. Inicialmente o órgão estava ligado ao Ministério da Justiça (MJ), mas, no ano de 2015, depois de sofrer algumas alterações, a Secretaria foi agregada ao Ministério das MuIheres, da Igualdade Racial e dos Direitos Humanos. Essa alteração ocorreu após uma reforma ministerial no governo da presidenta Dilma Rousseff.

Vale salientar que a Secretaria Especial dos Direitos Humanos (SEDH) tem por atribuições articular e instituir as políticas públicas voltadas para a promoção e efetivação dos direitos humanos no Brasil. A luta pelos direitos humanos significa buscar melhor qualidade de vida para os brasileiros, garantindo, assim, sua individualidade enquanto cidadão. Nessa direção, afirma Schuler (2008):

Hoje, temos uma legislação bastante avançada em relação aos direitos humanos. O direito interno já incorporou o conteúdo e os avanços contidos em vários instrumentos internacionais existentes, tanto no sistema global como no regional, de proteção e defesa dos direitos humanos, a exemplo da Declaração Universal dos Direitos Humanos, aprovada pela Assembléia Geral das Nações Unidas em 10 de dezembro de 1948, dos Pactos Internacionais de 1966, sobre direitos civis e políticos, e sobre direitos econômicos, sociais e culturais. No tocante aos planos nacionais, podemos mencionar o Plano Nacional de Educação em Direitos Humanos, lançado no dia 10 de dezembro de 2003, na gestão do governo Lula; o Plano Nacional para a Erradicação do Trabalho Escravo, o Programa Nacional dos Direitos Humanos, dentre outros. Há de se considerar, entretanto, que muitos desses avanços ainda esperam por ser materializados na prática (p. 144).

De acordo com Silva (2008), os direitos humanos possuem uma origem histórica, ao considerarmos que seu surgimento deriva de lutas enfrentadas pela humanidade como uma etapa no processo das transformações decorrentes dessas lutas e da busca da emancipação. Desse modo, destaca Rabenhorst (2008): 
A história dos direitos humanos no Brasil pode ser vista como obra de todos aqueles que, através de insurreições, rebeliões e revoltas, lutaram contra uma estrutura de dominação que vigorou em nosso país durante séculos e que ainda persiste em muitos aspectos, principalmente no que concerne às desigualdades sociais (p. 19).

Assim, os direitos humanos são históricos e não estão prontos e acabados; pelo contrário, eles estão em constante ebulição, isto é, em constante transformação. Como afirma Piovesan (2009), os DHs mudam através do tempo, respondendo às necessidades e situações específicas de cada momento, e nascem quando devem e quando podem nascer.

\section{A EDUCAÇÃO EM DIREITOS HUMANOS NA EDUCAÇÃO BÁSICA NA PERSPEC- TIVA DO PLANO NACIONAL DE EDUCAÇÃO EM DIREITOS HUMANOS}

É importante pensar-se em termos de Educação em Direitos Humanos (EDH), e para isso é necessário definir-se o seu significado. Antes de adentrar para tratar da EDH, é preciso salientar que, para consolidar a prática de proteção e respeito aos direitos humanos, faz-se necessária uma somatória de forças, e para isto é imprescindível que as instituições de ensino se coloquem como principais aliadas na disseminação dessa nova cultura. O Caderno de Educação em Direitos Humanos (CEDH), documento publicado em 2013, já apresenta as escolas e os demais espaços de aprendizagem como ambientes propícios para o processo de construção da cultura em direitos humanos.

A escola, ou qualquer ambiente de aprendizagem, é o espaço de convivência inicial do ser humano em formação, bem como uma atmosfera de convivência para os que buscam um objetivo em comum, que é a instrução. É muito importante que esse ambiente possa formar cidadãos inspirados no respeito ao próximo, na aceitação das diferenças (BRASIL, 2013b, p. 44).

Neste sentido, o espaço escolar é considerado o primeiro espaço social após a família. Por esse motivo, os espaços educacionais configuram-se como primordiais na disseminação da cultura em direitos humanos, posto que a escola tem como papel fundamental buscar formar cidadãos para exercer a cidadania na sociedade. Como afirma Carbonari (2008), "a escola é um lugar social no qual se estabelecem relações educativas específicas e fundamentais para a formação do humano" (CARBONARI, 2008, p. 159).

Diante disso, e levando em consideração a importância da escola em sua disseminação, o que é a educação em direitos humanos? Vários documentos foram construídos ao longo da história, enfatizando a sua importância. Pode-se entender que a educação em direitos humanos é um mecanismo ou ferramenta para a promoção da equidade social, bem como para a promoção do respeito à diferença. Nessa perspectiva, o Programa Mundial para Educação em Direitos Humanos (PMEDH) define a EDH como:

[...] um conjunto de atividades de educação, de capacitação e de difusão de informação, orientadas para criar uma cultura universal de direitos humanos. Uma educação integral em direitos humanos não somente proporciona conhecimentos sobre os direitos humanos e os mecanismos para protegê-los, mas que, além disso, transmite as aptidões necessárias para promover, defender e aplicar os direitos humanos na vida cotidiana (ONU, 2006, p. 1). 
Neste sentido, a EDH se apresenta como um meio para que os direitos humanos sejam efetivados e percam o caráter deturpado que ora recebem. A cultura em direitos humanos pode construir atitudes e comportamentos indispensáveis para a defesa e proteção dos direitos humanos. Para Benevides (2000), a EDH [...] é essencialmente a formação de uma cultura de respeito à dignidade humana através da promoção e da vivência dos valores da liberdade, da justiça, da igualdade, da solidariedade, da cooperação, da tolerância e da paz (p. 1).

Assim sendo, ao falar em EDH está-se pensando na formação de um cidadão que, mesmo tendo um posicionamento diferente, poderá expressar o que pensa sem desrespeitar a condição humana de ninguém, entendendo que essa condição é perpassada por profundas diferenças. Uma pessoa inspirada no respeito e na aceitação das diferenças, portanto, é uma pessoa educada para os direitos humanos. O que leva à "educação de que estamos falando é aquela centrada na humanização integral do ser humano" (CARBONARI, 2008, p. 159). De acordo com Dias (2008), falar em EDH é falar de uma educação

[...], que privilegia os processos educativos que tenham como objetivo formar cidadãos críticos e atuantes numa determinada sociedade. Uma educação que não discrimina, que promove o diálogo, a solidariedade, o respeito mútuo, a tolerância, e, sobretudo, a autonomia e a emancipação dos sujeitos envolvidos ( p. 158).

Sendo assim, educar crianças, adolescentes e jovens na perspectiva da educação em direitos humanos atualmente, é dar um norte novo para a construção de uma sociedade mais justa e humana, na qual a solidariedade, o respeito, a tolerância e a autonomia serão os princípios que estarão presentes nas relações sociais, o que resultará em uma sociedade mais igualitária. Como afirma Batista et al. (2015), a educação em direitos humanos é:

[...] um dos mais importantes instrumentos dentro das formas de combate às violações dos direitos fundamentais, pois educa propondo a valorização da dignidade, a tolerância e os princípios da democracia, que remontam aos ideais da Revolução Francesa, tais quais a liberdade, igualdade e fraternidade (p. 2).

É certo, também, que não se pode ser ingênuos e afirmar que a EDH pode ser entendida como a solução de todos os problemas ou aquela que vai resolver os conflitos sociais. Ela deve ser entendida como um caminho para a construção de uma nova cultura voltada para o respeito à dignidade humana. Ainda, de acordo com Dias (2008),

A cultura de direitos passa, necessariamente, por um efetivo diálogo entre saberes e práticas humanizadoras que conferem sentidos e significados à participação efetiva de todos os envolvidos no processo educativo que se desenrola na escola. Daí a importância da educação em Direitos Humanos (p. 158).

Neste sentido, levando em consideração a importância da EDH, é fundamental que as escolas a incluam em seu projeto político-pedagógico (PPP) de forma a contemplar ações fundadas nos princípios de convivência social, participação, autonomia e democracia (DIAS, 2008). As escolas precisam abraçar as propostas educativas produzidas no país para a instituição da cultura dos direitos humanos, pois uma educação à luz dessa cultura não será o fim de todos os desrespeitos, mas o início da tomada de consciência dos direitos que estão assegurados na lei. Educar nessa cultura é defender e aplicar os direitos humanos na vida cotidiana. Sader (2007); salienta que: 
Educar é assumir a compreensão do mundo, de si mesmo, da intrerrelação entre os dois. Pode ser uma compreensão real, que capte os mecanismos que, efetivamente, são produzidos e reproduzidos pelos homens no seu processo concreto de vida, ou, ao contrário, pode ser uma visão alienada que, ao invés de permitir essa compreensão, ocupa esse lugar na consciência das pessoas com mitos, com ilusões, com concepções que consolidem a incapacidade das pessoas de se compreenderem no mundo e compreenderem o mundo que, mesmo sem consciência, estão produzindo e reproduzindo, cotidianamente, nas suas vidas (p. 80-81).

Por isso, de acordo com o Caderno de Educação em Direitos Humanos (CEDH), "A construção de um conceito de direitos humanos para a sociedade deve ter como eixo fundamental a dignidade da pessoa humana, visando o integral desenvolvimento de seu potencial criador enquanto cidadão crítico e consciente de seus deveres e direitos" (BRASIL, 2013b, p. 16), uma vez que educar em direitos humanos é influenciar, compartilhar e consolidar mentalidades, costumes, atitudes, hábitos e comportamentos que decorrem, todos, daqueles valores essenciais, os quais devem se transformar em práticas (BENEVIDES, 2000).

A educação para os direitos humanos, na perspectiva do pensamento freiriano, por exemplo, valoriza o diálogo com os diversos saberes que circulam no nosso dia a dia e que possibilita compreender o mundo. Assim, a escola, ao trabalhar nessa perspectiva, precisa reconhecer e respeitar o conhecimento do outro. No entendimento de Freire (2002),

Se, de um lado, não posso me adaptar ou me "converter" ao saber ingênuo dos grupos populares, de outro não posso (...) impor-lhes arrogantemente o meu saber como o verdadeiro. O diálogo em que se vai desafiando o grupo popular a pensar sua história social com a experiência igualmente social de seus membros, vai revelando a necessidade de superar certos saberes que, desnudados vão mostrando sua "incompetência" para explicar os fatos (p. 32).

Neste sentido, é possível afirmar que se pode “[...] conceber a educação como uma condição básica para que os cidadãos possam operar plenamente enquanto seres humanos no contexto das sociedades modernas" (LEITE, 2011, p. 4). Já Batista et al. (2015, p. 2) salientam que a finalidade maior da EDH na escola é

[...] a constituição de uma cultura da democracia, do respeito às diferenças, da não discriminação e da paz. Esta educação permite a afirmação dos direitos fundamentais, conscientiza o cidadão de seu papel social na luta contra desigualdades e injustiças, ou seja, busca formar consciências cidadãs.

Como destaca Gohn (2012), a educação entra nesse processo de formação como um direito humano para o desenvolvimento do ser humano. Essa educação propõe a construção do ser cidadão, que tem a individualidade e a diversidade como princípio; um cidadão que vai fortalecer a cultura de respeito e da paz.

\subsection{Resgatando o plano nacional de educação em direitos humanos (PNEDH)}

Inicialmente é necessário destacar que o Plano Nacional de Educação em Direitos Humanos (PNEDH) surge de um compromisso do Estado brasileiro com a concretização dos direitos humanos, objetivando também a construção de uma sociedade civil organizada a partir do respeito à pessoa humana. O PNEDH é um documento que foi criado a partir da articula- 
ção institucional, envolvendo os três Poderes da República, em especial o Poder Executivo (governo federal, estaduais, municipais e do Distrito Federal), organismos internacionais, instituições de educação superior e a sociedade civil:

Ao mesmo tempo em que aprofunda questões do Programa Nacional de Direitos Humanos, o PNEDH incorpora aspectos dos principais documentos internacionais de direitos humanos dos quais o Brasil é signatário, agregando demandas antigas e contemporâneas de nossa sociedade pela efetivação da democracia, do desenvolvimento, da justiça social e pela construção de uma cultura de paz (BRASIL, 2007, p. 11).

Sendo assim, percebe-se, de forma clara, o reflexo dos documentos internacionais sobre EDH no PNEDH. Segundo Batista et al. (2015), foi em meio à Década para a Educação em Direitos Humanos das Nações Unidas (1995-2004) que:

[...] o governo brasileiro, atendendo indicações dos documentos da ONU, criou o Comitê Nacional de Educação em Direitos Humanos (CNEDH) e a partir daí começou o processo de elaboração do Plano Nacional de Educação em Direitos Humanos em 2003 (p. 16).

Assim, em conformidade com o Plano Mundial de Educação em Direitos Humanos (PMEDH), surge no nosso país, em 2003, o processo de construção do PNEDH. O processo de elaboração do PNEDH se deu, como citado anteriormente, a partir da criação do Comitê Nacional de Educação em Direitos Humanos (CNEDH), este, por sua vez, composto por especialistas, representantes da sociedade civil, instituições públicas e privadas e organizações internacionais.

Em resposta aos trabalhos do Comitê Nacional de Educação em Direitos Humanos, em dezembro de 2003 foi lançada, em parceria com o Ministério da Educação (MEC) e a Secretaria Especial de Direitos Humanos (SEDH), uma primeira versão do documento com orientações para que fosse criado um conjunto de ações objetivando a promoção de respeito à cultura dos direitos humanos; esse seria o primeiro resultado apresentado pelo mais novo mecanismo CNEDH, visando à construção futura do PNEDH:

O Plano Nacional de Educação em Direitos Humanos (PNEDH), lançado em 2003, está apoiado em documentos internacionais e nacionais, demarcando a inserção do Estado brasileiro na história da afirmação dos direitos humanos e na Década da Educação em Direitos Humanos, prevista no Programa Mundial de Educação em Direitos Humanos (PMEDH) e seu Plano de Ação10. São objetivos balizadores do PMEDH conforme estabelecido no artigo $2^{\circ}$ : a) fortalecer o respeito aos direitos humanos e liberdades fundamentais; $b$ ) promover o pleno desenvolvimento da personalidade e dignidade humana; $c$ ) fomentar o entendimento, a tolerância, a igualdade de gênero e a amizade entre as nações, os povos indígenas e grupos raciais, nacionais, étnicos, religiosos e lingüísticos; d) estimular a participação efetiva das pessoas em uma sociedade livre e democrática governada pelo Estado de Direito; e) construir, promover e manter a paz (BRASIL, 2007, p. 24).

No ano consecutivo do Comitê, abriu-se uma série de debates em torno do PNEDH, que, por sua vez, ocorreram em encontros, seminários e fóruns em âmbito internacional, nacional, regional e estadual:

Ao longo do ano de 2004, o PNEDH foi divulgado e debatido em encontros, seminários e fóruns em âmbito internacional, nacional, regional e estadual. Em 2005, foram realizados encontros estaduais com o objetivo de difundir o PNEDH, que resultaram em contribui- 
ções de representantes da sociedade civil e do governo para aperfeiçoar e ampliar o documento. Mais de 5.000 pessoas, de 26 unidades federadas, participaram desse processo de consulta que, além de incorporar propostas para a nova versão do PNEDH, resultou na criação de Comitês Estaduais de Educação em Direitos Humanos e na multiplicação de iniciativas e parcerias nessa área (BRASIL, 2007, p. 12).

Convém lembrar que em 2005 o plano passou por uma série de discussão em âmbito estadual, e como resultado dessas fases foi possível escutar a sociedade civil, registrando, assim, as suas contribuições no documento, bem como contribuindo para aperfeiçoar e expandir o documento (PNEDH). Somente em 2006 foram concluídos os trabalhos de construção do PNEDH. De acordo com Batista et al. (2015):

A sua atual e definitiva versão foi lançada em 2007, e contou com a revisão de professores e alunos de graduação e pós-graduação do Centro de Filosofia e Ciências Humanas da Universidade Federal do Rio de Janeiro (CFCH/UFRJ), e posterior à consulta popular, foi revisado e aprovado pelo CNEDH (p. 16-17).

Neste sentido, a estrutura do plano estabelece concepções, princípios, objetivos, diretrizes e linhas de ação contemplando cinco grandes eixos de atuação, sendo essas: Educação Básica, Educação Superior, Educação Não formal, Educação dos Profissionais dos Sistemas de Justiça e Segurança Pública e Educação e Mídia. Batista et al. (2015) afirma, ainda, que:

[...] o Plano Nacional de Educação em Direitos humanos visa desenvolver uma cultura em direitos humanos e do respeito, em que os direitos humanos possam ser praticados e vividos nos diferentes espaços da sociedade. O PNEDH surge como uma tentativa de se estabelecer um plano universal para a educação em direitos humanos embasado nos princípios de democracia e participação social. De acordo com os cinco eixos do Plano, é fundamental que o Estado pense conjuntamente com a sociedade, em estratégias que promovam os direitos humanos (p. 18).

Dessa forma, o PNEDH destaca-se como política pública, assumindo dois princípios importantes: o primeiro deles é consolidar uma sociedade que se fundamenta na cidadania, democracia e justiça social, e o segundo princípio é viabilizar mecanismos para a construção da cultura dos direitos humanos, que se consolida como uma política pública para a promoção da educação em direitos humanos no Brasil e formação de uma consciência cidadã:

O PNEDH, na condição de política pública, apresenta-se como um instrumento orientador e fomentador de ações educativas, no campo da educação formal e não formal, nas esferas pública e privada. Reflete as ações que estão sendo desenvolvidas no país, envolvendo iniciativas de instituições públicas, organizações da sociedade civil e contribuições recebidas por meio de consulta pública e das recomendações do documento da UNESCO sobre a Década das Nações Unidas para a Educação em Direitos Humanos e para uma Cultura de Paz (1995-2004) (SACAVINO, 2007, p. 464).

Como afirma Barreiro (2011), entretanto, a partir da elaboração do PNEDH "pode-se considerar que o Brasil iniciou um trabalho sistemático e institucionalizado para possibilitar e promover a educação em direitos humanos" (p. 71). É preciso acrescentar, aqui, que seria impossível levantar uma discussão sobre o tema se o plano não existisse. Mesmo que o plano tenha uma aplicabilidade questionável, é inegável que ele é um avanço significativo para a EDH no Brasil. 


\subsection{A educação básica na perspectiva do PNEDH e o papel da escola}

A Educação básica corresponde à escolaridade obrigatória e, apesar de ser estruturada por etapas e modalidades de ensino, não se limita a transmitir conhecimentos disciplinares, mas também compartilha valores. Dessa forma, levando em consideração a importância da educação básica na formação do ser humano, incluir os Direitos Humanos nos currículos escolares é de suma importância para o processo de fortalecimento de uma cultura que valorize a pessoa humana e sua dignidade. Nesse sentido, o PNEDH conceitua a EDH como:

[...] um processo sistemático e multidimensional que orienta a formação do sujeito de direitos, articulando as seguintes dimensões:

a) apreensão de conhecimentos historicamente construídos sobre direitos humanos e a sua relação com os contextos internacional, nacional e local;

b) afirmação de valores, atitudes e práticas sociais que expressem a cultura dos direitos humanos em todos os espaços da sociedade;

c) formação de uma consciência cidadã capaz de se fazer presente em níveis cognitivo, social, ético e político;

d) desenvolvimento de processos metodológicos participativos e de construção coletiva, utilizando linguagens e materiais didáticos contextualizados;

e) fortalecimento de práticas individuais e sociais que gerem ações e instrumentos em favor da promoção, da proteção e da defesa dos direitos humanos, bem como da reparação das violações (BRASIL, 2008, p. 25).

Fica evidente que a educação voltada aos direitos humanos está para além dos conteúdos programáticos do livro didático ou, até mesmo, para além de meramente estudar para galgar aprovação no vestibular ou Exame Nacional do Ensino Médio (Enem) e ser um bom profissional. É uma educação voltada para o respeito à vida, para a justiça e o respeito pela diferença. Em virtude do que foi mencionado, e para a construção de uma cultura em direitos humanos, o PNEDH apresenta alguns princípios que deverão ser adotados pela educação básica:

a) a educação deve ter a função de desenvolver uma cultura de Direitos Humanos em todos os espaços sociais;

b) a escola como espaço privilegiado para a construção e consolidação da cultura de Direitos Humanos, deve assegurar que os objetivos e as práticas a serem adotados sejam coerentes com os valores e princípios da Educação em Direitos Humanos;

c) a educação em direitos humanos, por seu caráter coletivo, democrático e participativo, deve ocorrer em espaços marcados pelo entendimento mútuo, respeito e responsabilidade;

d) a educação em direitos humanos deve estruturar-se na diversidade cultural e ambiental, garantindo a cidadania, o acesso ao ensino, permanência e conclusão, a eqüidade (étnico-racial, religiosa, cultural, territorial, físico-individual, de nacionalidade, dentre outras) e a qualidade da educação;

e) a educação em direitos humanos deve ser um dos eixos fundamentais da educação básica e permear o currículo, a formação inicial e continuada dos profissionais da educação, o projeto político pedagógico da escola, os materiais didático-pedagógicos, o modelo de gestão e avaliação;

f) a prática escolar deve ser orientada para a educação em direitos humanos, assegurando o seu caráter transversal e a relação dialógica entre os diversos atores sociais (BRASIL, 2007, p. 32). 
Assim, a escola, ao educar em direitos humanos, deve assegurar aos alunos o primeiro direito fundamental, sem o qual os outros não têm sentido - o de ser pessoa. O processo educativo "pressupõe o reconhecimento da pluralidade e da alteridade, condições básicas da liberdade para o exercício da crítica, da criatividade, do debate de ideias e para o reconhecimento, respeito, promoção e valorização da diversidade" (BRASIL, 2007, p. 31). De acordo com Dias (2008), com base no Plano Nacional de Educação em Direitos Humanos (2007), a escola:

[...] no âmbito específico de sua atuação, pode contribuir para a realização de ações educativas que visem fomentar/estimular/promover a cultura dos direitos humanos mediante o exercício de práticas educativas de promoção e fortalecimento dos direitos humanos no espaço escolar, ajudando a construir uma rede de apoio para enfrentamento de todas as formas de discriminação e violação dos direitos (DIAS, 2008, p. 158).

Assim sendo, levando em consideração a importância da escola como um espaço de socialização e disseminação de conhecimento e onde os sujeitos estão num processo de formação e construção desse conhecimento, faz-se necessário que a escola inclua em seu currículo a prática dos direitos humanos. Com a temática dos direitos humanos sendo incluída no currículo escolar, pretende-se obter uma educação que promova o respeito à diversidade. Levando-se em consideração esses aspectos, a professora Adelaide Alves Dias (2009) salienta que a escola tem como função social:

[...] sistematizar e disseminar os conhecimentos historicamente elaborados e compartiIhados por uma sociedade. Por isso, os processos educativos em geral, e, principalmente, aqueles que ocorrem em seu interior, constituem-se em dinâmicas de socialização da cultura (p. 158).

Ao fazer tal afirmação, Dias (2008) faz refletir que os espaços educacionais de ensino básico se qualificam como principais espaços para a disseminação da cultura em direitos humanos, por meio de processos educativos que, por sua vez, devem compreender em si o princípio da dignidade da pessoa humana. Como bem afirma Freire (1980, p. 25), "a educação para a libertação é um ato de conhecimento e um método de ação transformadora que os seres humanos devem exercer sobre a realidade". Dessa forma, é de suma importância a inserção da educação em direitos humanos no processo pedagógico, como afirma Bittar (2008):

[...] neste contexto de amorfismo, de apatia diante do real, de indiferença ao outro, de crescimento do individualismo materialista, de indiferença perante tudo e todos, que o colorido do real seja retomado em sala de aula. Por isso, a educação desafiada deve, sobretudo, sensibilizar, agindo de modo a ser mais que instrutiva (somatória de informações acumuladas), enfatizando-se o seu aspecto formativo (geradora da autonomia do pensar) (p. 174).

Desse modo, "a escola constitui-se como uma das mais importantes organizações sociais que constrói, por meio das relações que se estabelecem no seu interior, inúmeros princípios concernentes a uma sociedade mais justa e igualitária" (ZLUHAN; RAITZ, 2014, p. 32). Destaca-se aqui a necessidade de ver a escola como um campo de construção de uma sociedade mais justa, humanizada, onde a diferença não seja justificativa para o desrespeito, mas para justificar a igualdade e o respeito aos semelhantes. Zluhan e Raitz (2004) ressaltam ainda que: 
[...] a escola é um espaço de circulação de culturas, diferenças e singularidades, deve-se garantir que os direitos humanos se transformem na base das relações e que a falta de entendimento, a ausência de escuta do outro, a destruição, a morte, amplamente divulgadas pelos adultos e pela mídia, se transformem em objeto de diálogo e reflexão (p. 32).

Zluhan e Raitz (2014) apontam o caminho que deve ser percorrido para transformar a escola tradicional em um local do desfile das diferenças. É necessário que as escolas se tornem espaços de diálogo e reflexão e eduquem os alunos no sentido de que ela é um espaço de pluralidades; logo, isso reflete na sociedade, tendo em vista que a escola é a réplica reduzida da sociedade. Coroborando, Dias (2008) afirma:

A concretização da educação em direitos humanos nas escolas torna-se factível na medida em que este espaço possa estimular, propor, apoiar e elaborar propostas de natureza artístico-culturais que visem ao combate de toda forma de preconceito, de intolerância e de discriminação no espaço escolar. Valorizar as diversas manifestações culturais, de cunho artístico, religioso e desportivo dos variados grupos que compõem a sociedade brasileira pode ser uma das formas de a escola contribuir para a efetivação da cultura dos direitos humanos (p. 159).

Por isso, a escola, no desenvolvimento de sua função social de formação da personalidade humana, deve contribuir para que haja tolerância e motivar práticas democráticas em sala de aula e fora dela. Logo, está contribuindo com a construção e a efetivação da cultura em diretos humanos. Diante disso, como salienta Araújo (2008):

Será que a escola que hoje conhecemos permite, de fato, que tais objetivos sejam alcançados? [...] Na realidade concreta das escolas e das salas de aula o que vemos é uma preocupação quase que exclusiva com a transmissão de alguns dos conteúdos científicos acumulados pelas diferentes culturas e pela humanidade. A preocupação dos currículos é com o ensino da língua, das matemáticas, das ciências, da natureza sócio-política-econômica da humanidade e das artes. [...] Nos parece que este modelo de escola não conseguirá atingir os objetivos de construção da cidadania e da democracia social (p. 164).

De uma forma mais objetiva, o que se está falando é que a escola precisa ser entendida como um espaço que está para além da transmissão do conhecimento já elaborado. Os espaços educacionais não devem estar destinados à mera função "conteudista", embora esta seja muito importante. Zluhan e Raitz (2014) ressaltam que

A escola não pode ser somente considerada transmissora de conteúdos, mas, sobretudo, um local privilegiado de aprendizagens e vivências cidadãs e democráticas, e, quando se fala na defesa, na efetivação e na universalização dos direitos humanos, precisa-se considerar os seres humanos/alunos como seres sociais, inseridos em uma organização social, na qual devem ser asseguradas as condições para que eles se desenvolvam e venham a viver com dignidade e igualdade (p. 34).

Como assevera Candau (1998), "a Educação em Direitos Humanos potencializa uma atitude questionadora, desvela a necessidade de introduzir mudanças, tanto no currículo explícito, quanto no currículo oculto, afetando assim a cultura escolar e a cultura da escola" (p. 36). Instituir EDH é romper com as amarras do currículo entendido por tradicional, e isso é romper com o currículo que coloca o discente como um ser sem luz. 
A escola, ao levantar o debate sobre a $E D H$, deve ter como base a mudança em seu currículo tradicional. Isso é pensar na mudança em todos os elementos que dão a sua sustentação enquanto instituição, seja o currículo explícito ou oculto, seja o projeto político-pedagógico (PPP), ou até mesmo o regimento escolar, devem ser construídos à luz do que propõe os Direitos Humanos. Isso é o zelo pela condição humana. Assim sendo, e levando em consideração os currículos das escolas do país, é indiscutível que existe a necessidade de estabelecimento da EDH nas redes educacionais.

Ainda é preciso salientar, também, que a EDH precisa se tornar uma política pública de Estado, o que implica afirmar que os chefes do Poder Executivo são os responsáveis por pensar e fomentar ações que contribuam para o fortalecimento e concretização da educação em direitos humanos. Fazer tal afirmativa parte do entendimento de "[...] que as políticas públicas devem ser do Estado e não de governos, para que possam consolidar-se e garantir sua efetividade e continuidade" (SILVA; TAVARES, 2013, p. 53). Levando-se em conta o que afirma Schuler (2008):

A política dos direitos humanos dentro do cenário das políticas públicas, em especial das políticas educacionais, possui um importante papel na luta pela minimização da criminalidade, da violência, da miséria, das violações aos direitos humanos (p. 150).

É certo que o PNEDH foi lançado oficialmente no ano de 2007, o que significa que em mais de dez anos de história não foi ainda sequer efetivada a prática da educação em direitos humanos (EDH) no dia a dia das escolas. Assim sendo, pode-se afirmar que, hoje, não existe a necessidade de construir outros documentos para fazer valer o que está garantido no PNEDH, mas existe a necessidade de cobrar e mostrar aos governantes que eles são os responsáveis em fortalecer a proposta da EDH que já está posta.

Neste sentido, reside a importância da efetivação e reflexão dos direitos humanos na educação básica, visando à formação de uma rede de proteção e de resistência à violação dos direitos humanos. As escolas devem se constituir em um espaço de reflexão-ação, contribuindo para a transformação da realidade social, quando constantemente os direitos humanos são desrespeitados.

O PNEDH, espelhando-se no plano mundial, atribui às Instituições de Ensino Superior (IES) a tarefa de desenvolver cidadãos hábeis em participar de uma sociedade livre, democrática, que consegue entender as diferenças seja elas quais forem (BRASIL, 2007).

Para que isso seja concretizado há, porém, 21 ações que recebem o nome de Ações Programáticas. Tais propostas sugerem às Instituições de Ensino Superior desde a proposta da educação em direitos humanos para subsidiar as diretrizes curriculares das áreas de conhecimento das IES, até a criação de um Fundo Nacional de Ensino, Pesquisa e Extensão, que tenha como objetivo principal apoiar projetos que discutam o tema educação em direitos humanos.

O PNEDH ainda demonstra uma preocupação de educar para os direitos humanos também as pessoas que frequentam os espaços de Educação Não Formal. Neste sentido, a educação em direitos humanos na modalidade não formal é orientada por meio de princípios da emancipação e da autonomia. Assim sendo, colocar a Educação Não Formal para caminhar ao lado da educação em direitos humanos é dar uma contribuição permanente ao “[...] proces- 
so de sensibilização e formação de consciência crítica, podendo ser compreendida como [...] educação para a vida no sentido de garantir o respeito à dignidade do ser humano" (BRASIL, 2008, p. 43).

Educar para os direitos humanos, seja em qualquer modalidade educacional, é contribuir para que as pessoas possam se respeitar e compreender as limitações e diferenças dos seus semelhantes. Daí, então, a importância da Educação Não Formal na função de informar e colaborar no processo de sensibilizar e conscientizar os sujeitos, estimulando a "[...] capacidade de as pessoas identificarem as violações dos direitos e exigirem sua apuração e reparação" (BRASIL, 2008, p. 43).

\section{EDUCAÇÃO EM DIREITOS HUMANOS NUMA ESCOLA DO CAMPO}

O campo da pesquisa foi a Escola Estadual de Ensino Fundamental e Médio Juarez Maracajá, que está localizada no município de Gurjão, no Cariri Oriental do Estado da Paraíba. A Escola Juarez Maracajá pertence ao poder público municipal, e responde pelo Ensino Médio, contando com 1 diretor e 13 professores.

$\mathrm{Na}$ pesquisa para identificar o entendimento dos discentes e dos professores sobre a temática dos diretos humanos, os questionários construídos continham questões abertas, de múltipla escolha e mistas. Nesta pesquisa foram aplicados 32 questionários: 26 para alunos e 6 para os professores do 1을 30 ano do Ensino Médio. Em um primeiro momento foi realizado um levantamento bibliográfico de livros e artigos, como também de sites com os seguintes temas: Direitos humanos e Educação em direitos humanos. Em um segundo momento foi realizada a pesquisa de campo na referida escola.

Quanto à faixa etária dos alunos pesquisados, que varia de 14 a 21 anos de idade, dos quais $23 \%$ são de 14 a 15 anos, 58\% estão na faixa etária de 16 a 17 anos, 15\% estão entre 18 a 19 anos e 4\% estão na idade de 20 a 21 anos. De acordo com os dados coletados, 73\% dos alunos pesquisados residem na zona urbana e apenas $27 \%$ residem na zona rural do município.

Buscou-se, também, identificar qual o entendimento dos alunos sobre os direitos humanos; assim, quando questionados sobre o que significa os direitos humanos, a maioria dos alunos apresentou sua compreensão, mas nem todos demonstraram ter conhecimento sobre a temática. Dos 26 alunos pesquisados, a maioria respondeu sem muita clareza. Diante das respostas verificou-se a necessidade de um trabalho pedagógico voltado para a educação em direitos humanos na escola. Como afirma Dias (2008), exige a adoção de práticas orientadas criticamente para completar a ressignificação da capacidade de pensar, agir, sentir e julgar na direção da promoção dos direitos humanos, capacitando-os para denúncia das violações desses direitos.

Questionou-se se os alunos têm acesso a materiais informativos sobre direitos humanos, e $69 \%$ desses responderam que sim, enquanto $31 \%$ dos alunos responderam que não têm acesso a nenhum material que aborde a temática dos direitos humanos. Esse acesso, segundo eles, processa-se por intermédio da televisão e da internet. Desse modo, quando abordou-se qual, ou quais, disciplina(s) apresenta $(\mathrm{m})$ temáticas relacionadas aos direitos humanos, a maioria apontou história, sociologia e filosofia. Os informantes discentes, porém, 
não são precisos a mostrar como esses conteúdos são trabalhados. Também buscou-se saber qual a atividade realizada sobre os direitos humanos que marcou o estudo dos alunos, e a maioria teve dificuldades em lembrar.

A disciplina de língua portuguesa também foi apontada pelos alunos, por repetidas vezes, como uma das disciplinas que discute o tema dos direitos humanos em sala de aula. Isso demonstra que a abordagem dos direitos humanos não se restringe somente às disciplinas das ciências humanas e sociais.

Quadro 1 - Situações de violação dos direitos humanos identificadas pelos alunos na sociedade

\begin{tabular}{|l|c|}
\hline Situações de violação dos direitos humanos & Respostas \\
\hline Agressão física contra uma pessoa & 18 \\
\hline A prática de linchamento a acusados de algum crime & 10 \\
\hline Falta de assistência básica de saúde & 14 \\
\hline Exclusão da pessoa com deficiência da sociedade & 16 \\
\hline Degradação do meio ambiente & 03 \\
\hline Carência de moradia para os cidadãos & 11 \\
\hline A prática de bullying & 17 \\
\hline Nenhuma das alternativas & 01 \\
\hline
\end{tabular}

Fonte: Pesquisa de campo.

A violência é recorrente no depoimento dos discentes. Diante da análise das respostas dos alunos, fica evidente a necessidade de a escola inserir as temáticas dos direitos humanos nos conteúdos tradicionais do currículo escolar. É perceptível que é mais fácil os alunos relacionarem casos de violação com violência mais concreta, e poucos relacionaram com a questão ambiental.

Quanto à percepção dos professores sobre o que significa os direitos humanos, a maioria deles relacionou os direitos humanos à ideia de liberdade, igualdade, universalidade e liberdade de expressão. Somente um deles, dos seis entrevistados, apresentou uma resposta confusa. O Quadro 2 resume as percepções.

Quadro 2 - O que significa os direitos humanos na concepção dos professores

\begin{tabular}{|l|l|}
\hline PROFESSORES & \multicolumn{1}{c|}{ RESPOSTAS } \\
\hline Professor 1 & $\begin{array}{l}\text { É respeitar os direitos humanos. É universal, o ser humano ao nascer ele está } \\
\text { para usufruir de liberdade de expressão, promover a paz, conviver em igualda- } \\
\text { de com os demais. }\end{array}$ \\
\hline Professor $\mathbf{2}$ & $\begin{array}{l}\text { Organização das nações unidas que afirma que todos os seres humanos nascem } \\
\text { livres e iguais em dignidade e direitos. }\end{array}$ \\
\hline Professor $\mathbf{3}$ & $\begin{array}{l}\text { São direitos inerentes a todos os seres humanos sem distinção de raça, sexo e } \\
\text { religião. }\end{array}$ \\
\hline Professor $\mathbf{4}$ & $\begin{array}{l}\text { São direitos e liberdades básicas dos indivíduos que devem ser mantidos e res- } \\
\text { peitados. }\end{array}$ \\
\hline Professor $\mathbf{5}$ & São ações que levam em conta o respeito à dignidade do cidadão. \\
\hline Professor $\mathbf{6}$ & Liberdade de pensamento, de expressão, de igualdade perante a lei. \\
\hline
\end{tabular}


Quando perguntados se a forma como a temática dos direitos humanos vem sendo trabalhada nas suas aulas é satisfatória, a maioria dos professores respondeu que não, e apenas um professor respondeu que não trabalha com as temáticas dos direitos humanos. Os professores 1 e 4 afirmaram que o grande volume de atividades e conteúdos fazem com que os direitos humanos não sejam o foco, apesar de estar em todos os conteúdos, e também pensam que falta o corpo docente se sensibilizar e abordar o assunto de forma sistemática.

É importante destacar que não há uma disciplina, ou componente, que venha a estabelecer uma ênfase nesse(s) conteúdo(s). Esses profissionais foram questionados se já tiveram acesso ao Plano Nacional de Educação em Direitos Humanos (PNEDH), e apenas 1, dos 6 professores pesquisados, demonstrou ter tido acesso, o que mostra que esse documento, essencial para a discussão pedagógicas e para a inserção de conteúdos nos componentes do fluxograma do Ensino Médio, não vem sendo considerado nas atividades de planejamento.

Diante das respostas elencadas pelos docentes, vale salientar, como afirma Candau e Sacavino (2013), que a educação em Direitos Humanos não pode ser reduzida à introdução de alguns conteúdos nos diferentes âmbitos educativos. Trata-se de criar ambientes em que os Direitos Humanos impregnem todas as relações e componentes educativos. Além disso, Segundo Candau (2008):

(...) é insuficiente promover eventos e atividades esporádicas, orientadas fundamentalmente a sensibilizar e motivar para as questões relacionadas com os Direitos Humanos. Torna-se imprescindível integrar a educação em Direitos Humanos nos projetos político-pedagógicos das escolas e comprometer no seu desenvolvimento as diferentes áreas curriculares. É, também, de especial importância desenvolver processos formativos que permitam articular diferentes dimensões - cognitiva, afetiva, artística e sócio-política fundamentais para a educação em Direitos Humanos, assim como utilizar estratégias pedagógicas ativas, participativas e de construção coletiva que favoreçam educarmos em Direitos Humanos (p. 194).

Ao se indagar a respeito do que fazer para evitar o desrespeito aos direitos humanos, 11 alunos não responderam a questão; já a maioria elencou diversas formas que, possivelmente, podem contribuir para evitar o desrespeito, como podemos verificar por meio de exemplos de respostas claras de alguns alunos, indicando formas de evitar o desrespeito:

Aluno 12: "Respeitar o próximo, diálogos e não à violência".

Aluno 11: Se colocar no lugar do próximo e ter mais consciência de quando se desrespeita os direitos humanos".

Aluno 9: "Creio que isso só iria acontecer quando a própria sociedade se conscientizasse do quão ridículo são os seus atos".

Aluno 10: "Respeitar as opiniões dos semelhantes".

Aluno 16: "Nos conscientizarmos".

Aluno 19: "Várias coisas, mas primeiro temos que conscientizar as pessoas sobre tais atos que infligem com a lei do nosso país".

Aluno 21: "Mais informações sobre o assunto de direitos humanos como: palestras e mais educação que o nosso Brasil terá consciência". 
Aluno 25: "Promover palestras que incentivem as pessoas a viverem de uma forma que não haja desrespeito aos direitos humanos; criação de leis para punir as pessoas que desrespeitarem os direitos humanos".

Aluno 23: "O governo e o Ministério da Educação devem conscientizar a sociedade, tendo palestras e anúncios em TV e também na Web ou até mesmo criar novas normas em uma sociedade, com novas leis".

Aluno 26: "Respeitar a todos e tratar de forma igualitária".

Essas respostas apresentam chaves de pensamento que podem ser exploradas nas aulas, inserindo as temáticas relacionadas aos direitos humanos no currículo escolar. Considerando a educação como necessária em relação a uma parte substancial do desenvolvimento integral humano, é fundamental uma educação voltada não somente para aprender os conteúdos, mas que contribua para a construção da cidadania. Como salienta Araújo (2008):

Um dos objetivos centrais da educação deve ser o de promover a construção de personalidades morais autônomas, críticas, que almejem o exercício competente da cidadania, embasada nos princípios democráticos da justiça, da igualdade, da eqüidade e da participação ativa de todos os membros da sociedade na vida pública e política (p. 164).

Foram aplicados questionários com os professores que ministram sociologia, história, geografia, matemática, português e biologia nas turmas do 10 ao 30 anos do Ensino Médio. Vale salientar que foram pesquisados seis professores com o objetivo de identificar a sua concepção e como trabalham a temática dos direitos humanos em sala de aula.

Os professores foram questionados se a temática dos direitos humanos é contemplada no ensino em sala de aula; a maioria dos professores respondeu que sim, porém apenas dois professores foram precisos nas suas respostas.

Quadro 3 - Respostas dos professores a respeito se a temática dos direitos humanos é contemplada no ensino em sala de aula

\begin{tabular}{|l|l|}
\hline PROFESSORES & \multicolumn{1}{|c|}{ RESPOSTAS } \\
\hline Professor 1 & $\begin{array}{l}\text { Sim. A partir do momento que o ser humano nasce passa a ter contato com a } \\
\text { necessidade de vivenciar e na escola passa e se conscientizar com orientações e } \\
\text { debates do dia a dia. }\end{array}$ \\
\hline Professor 2 & $\begin{array}{l}\text { Sim. Porque os alunos têm que saber que direitos humanos são dotados de razão } \\
\text { e de consciência, e devem agir uns para os outros em espírito de fraternidade. }\end{array}$ \\
\hline Professor $\mathbf{3}$ & Sim. De forma transversal \\
\hline Professor 4 & $\begin{array}{l}\text { Em algumas disciplinas existe essa abordagem, cabe ao docente contemplar essa } \\
\text { discussão em sua área, porém ainda temos um currículo estático que não contribui } \\
\text { para isso. }\end{array}$ \\
\hline Professor 5 & $\begin{array}{l}\text { Sim, em alguns casos, dependendo do(a) professor(a). Infelizmente muitos educa- } \\
\text { dores acham que é um tema insignificante ou de difícil abordagem. }\end{array}$ \\
\hline Professor $\mathbf{6}$ & Não utilizo muito nas minhas aulas \\
\hline
\end{tabular}

Fonte: Pesquisa de campo.

Outro ponto importante na pesquisa foi investigar em que conteúdos os docentes inseriam as temáticas relacionadas com os direitos humanos. Somente o professor 2 não soube indicar em quais conteúdos da disciplina de geografia poderiam ser trabalhados os $\mathrm{DHs}$. $\mathrm{Na}$ 
verdade, falta ao docente a visão de que poderiam ser inseridos em conteúdos geográficos, como população, urbanização, processo de "favelização do Brasil", globalização, emigração, migração, imigração, meio ambiente, cidades, êxodo rural e urbano, conteúdos da geografia que têm uma relação direta com os diretos humanos. O Quadro 4 traz as respostas em destaque.

Quadro 4 - Conteúdos que são abordados na temática dos direitos humanos pelos professores em sala de aula

\begin{tabular}{|l|l|}
\hline PROFESSORES & \multicolumn{1}{c|}{ RESPOSTAS } \\
\hline Professor 1 & $\begin{array}{l}\text { Grécia e Roma; Reforma Protestante e Contra-Reforma; Primeira e Segunda Guerra } \\
\text { Mundial; golpe de 1964; abolição da escravatura. }\end{array}$ \\
\hline Professor $\mathbf{2}$ & $\begin{array}{l}\text { Trabalhar os direitos humanos no contexto escolar, nos conteúdos encontrados na } \\
\text { aquisição e no desenvolvimento de competências práticas. Através de projetos. }\end{array}$ \\
\hline Professor 3 & $\begin{array}{l}\text { Pluralidade, cultura, sexualidade, democracia e cidadania, sociedade de direitos e } \\
\text { outros. }\end{array}$ \\
\hline Professor 4 & Racismo, tráfico humano, ética, violência contra a mulher, saúde, educação. \\
\hline Professor 5 & $\begin{array}{l}\text { No caso da disciplina matemática, alguns poucos temas abordam os direitos huma- } \\
\text { nos, como matemática financeira, por exemplo. }\end{array}$ \\
\hline Professor 6 & Não trabalho. \\
\hline
\end{tabular}

Fonte: Pesquisa de campo.

Por conseguinte, os professores afirmam, em sua maioria, que tiveram contato com as temáticas relacionadas aos direitos humanos em cursos de Graduação, por meio de livros, internet, cursos de atualização, jornais, TV, revistas e contato com outros professores.

Outro ponto importante para o desenvolvimento do processo de ensino aprendizagem é saber quais os recursos didáticos empregados. O Quadro 5 apresenta as respostas dos professores acerca de quais instrumentos se valem ao desenvolver conteúdos que trazem elementos, centrais ou periféricos, de direitos humanos; ainda são utilizados os quadros a giz, os livros didáticos, cartazes, aula de campo, filmes, músicas, biblioteca, gravuras e datashow, como consta no Quadro 5:

Quadro 5 - Recursos didáticos utilizados pelos professores para o desenvolvimento das temáticas dos direitos humanos durante as aulas com os alunos

\begin{tabular}{|l|l|}
\hline PROFESSORES & \multicolumn{1}{|c|}{ RESPOSTAS } \\
\hline Professor $\mathbf{1}$ & Livro didático; biblioteca; quadro; giz. \\
\hline Professor $\mathbf{2}$ & Cartazes; datashow; livro didático; biblioteca. \\
\hline Professor $\mathbf{3}$ & Cartazes; datashow; livro didático; biblioteca; gravuras; filmes; aula de campo. \\
\hline Professor $\mathbf{4}$ & Cartazes; datashow; filmes. \\
\hline Professor $\mathbf{5}$ & Cartazes; datashow; músicas. \\
\hline Professor $\mathbf{6}$ & Datashow; livro didático; filmes. \\
\hline
\end{tabular}

Fonte: Pesquisa de campo. 
No Quadro 6 tem-se as respostas acerca do contato dos docentes com o PNEDH, posto que a minoria teve acesso a esse plano e a maioria não teve acesso e não justificou o porquê. Isso preocupa sobremaneira, pois esse documento é a base para qualquer discussão curricular acerca de conteúdos relacionados aos direitos humanos na educação brasileira. É preciso apresentar o Plano Nacional de Educação em Direitos Humanos aos professores e discutir formas de executá-lo.

Quadro 6 - Se os professores já tiveram acesso ao Plano Nacional de Educação em Direitos Humanos

(PNEDH), caso a resposta fosse negativa, explicasse os motivos, e se sim, o que achou

\begin{tabular}{|l|l|}
\hline PROFESSORES & \multicolumn{1}{|c|}{ RESPOSTAS } \\
\hline Professor $\mathbf{1}$ & $\begin{array}{l}\text { Sim, no Plano Nacional de Educação sempre foi discutido e colocado como obriga- } \\
\text { tório, visando à questão da cidadania, onde se concretiza na prática o exercício na } \\
\text { sociedade. }\end{array}$ \\
\hline Professor $\mathbf{2}$ & Não. Acesso só de livros, conversas e pesquisas. \\
\hline Professor $\mathbf{3}$ & Não. \\
\hline Professor $\mathbf{4}$ & Não tive acesso ainda. \\
\hline Professor $\mathbf{5}$ & Sim. \\
\hline Professor $\mathbf{6}$ & Não. \\
\hline
\end{tabular}

Fonte: Pesquisa de campo.

Em contraposição ao que foi afirmado nos Quadros supracitados, os docentes revelam considerar importante abordar essa temática em suas aulas, embora não façam ou não saibam fazer. A maioria dos educadores classificou a temática dos direitos humanos como importante e de grande relevância para ser trabalhada em sala de aula. O professor 6 , no entanto, não respondeu o questionamento, afirmando que não podia opinar, conforme é demonstrado no Quadro 7.

Quadro 7 - A importância que os educadores atribuem à temática dos direitos humanos

\begin{tabular}{|l|l|}
\hline PROFESSORES & \multicolumn{1}{c|}{ RESPOSTAS } \\
\hline Professor 1 & $\begin{array}{l}\text { Muito importante, já que através do exercício desta temática podemos preparar o } \\
\text { cidadão para que ele viva com dignidade, reconhecendo melhor os valores de um } \\
\text { povo. }\end{array}$ \\
\hline Professor 2 & $\begin{array}{l}\text { A importância de que os alunos irão ser pessoas de bem sempre respeitando todas } \\
\text { as pessoas. }\end{array}$ \\
\hline Professor 3 & $\begin{array}{l}\text { Enquanto educadora, acredito que seja de suma importância, uma vez que são } \\
\text { questões que permeiam todas as questões da vida social. }\end{array}$ \\
\hline Professor 4 & $\begin{array}{l}\text { É uma temática relevante, posto que o sujeito precisa ser conhecedor de seus direi- } \\
\text { tos, deveres para poder reivindicá-los. }\end{array}$ \\
\hline Professor 5 & $\begin{array}{l}\text { É uma temática de fundamental importância, visto que leva em consideração "o ser } \\
\text { humano" na sua essência. }\end{array}$ \\
\hline Professor $\mathbf{6}$ & Não posso opinar. \\
\hline
\end{tabular}

Fonte: Pesquisa de campo. 
Quando questionados em relação às dificuldades encontradas em trabalhar a temática dos direitos humanos nas aulas, estas foram apresentadas pelos professores: a falta de atenção dos alunos em absorver as informações, transversalizar os conteúdo com as questões dos direitos humanos em sua disciplina, a carência de material didático, a falta de engajamento da equipe da escola e planejamento por parte dos docentes. São sintomáticas essas respostas, pois apontam para uma multicausalidade, sendo difícil ver um responsável isoladamente, mas uma falha sistêmica na construção do trabalho no ambiente escolar, desde o planejamento e concepção das disciplinas até o processo de execução delas no cotidiano escolar.

Quadro 8 - Violação dos direitos humanos

\begin{tabular}{|l|c|}
\hline \multicolumn{1}{|c|}{ Situações de violação dos direitos humanos } & Quantidade de professores \\
\hline Agressão física contra uma pessoa & 5 \\
\hline A prática de linchamento a acusados de algum crime & 4 \\
\hline Falta de assistência básica de saúde & 4 \\
\hline Exclusão da pessoa com deficiência da sociedade & 4 \\
\hline Degradação do meio ambiente & 4 \\
\hline Carência de moradia para os cidadãos & 4 \\
\hline A prática de bullying & 5 \\
\hline Nenhuma das alternativas & 0 \\
\hline
\end{tabular}

Fonte: Pesquisa de campo.

O Quadro 8 apresenta a real noção de que os professores sabem identificar questões relacionadas às violações aos direitos humanos, inclusive assimilando que questões ambientais podem ser relacionadas a essa modalidade de lesão a direitos. Apesar, porém, de um conhecimento do senso comum, os docentes têm dificuldades em sistematizar esse conhecimento e transformar possibilidades de conteúdos a serem discutidos em sala de aula.

\section{CONSIDERAÇÕES FINAIS}

O Plano Nacional de Educação em Direitos Humanos compõe as diretrizes essenciais para os conteúdos transversais em direitos humanos, desde o planejamento e concepção dos mesmos no âmbito das escolas e Secretarias de Educação no Brasil até sua execução no cotidiano escolar. Talvez o modelo de competências e atribuições da educação às diversas esferas administrativas nacionais (União, Estados, Municípios e Distrito Federal) dificulte o cumprimento dessas diretrizes. Essa é apenas uma hipótese para trabalhos futuros, mas decorreu da análise dos problemas vivenciados numa escola situada num rincão remoto dessa vasta nação, que, talvez, se coadune com outras realidades semelhantes.

Percebeu-se que os alunos conhecem a realidade de violência e violação aos direitos humanos que permeia seu dia a dia e de outras regiões. As respostas, porém, são baseadas, geralmente, no senso comum, e associam muito essa modalidade de direito àqueles relacionados com a privação de liberdade dos apenados. Por outro lado, os professores apresentam certo despreparo e desinformação, sendo necessário um processo de capacitação, que não seria satisfatório em si mesmo, mas deveria ser acompanhado de monitoramento, por meio de planejamentos e discussões avaliativas. 
Existe um vácuo deixado pela escola na "exploração" das temáticas relacionadas aos direitos humanos, ficando ela à margem de um papel protagonista no processo de ensino e aprendizagem das mesmas. Talvez se esse papel se inverter ter-se-á um reflexo direto na sociedade, o que não se pode garantir, mas é necessário ser experimentado no fazer escolar e sentido na sociedade com os frutos colhidos, porém isso é um processo de longo prazo.

Existe a necessidade de um trabalho pedagógico voltado para a Educação em Direitos Humanos, pois as ideias sobre o tema ainda são muito vagas, imprecisas, e denotam ausência de uma formação cidadã integradora que apresente, de forma contextualizada, os direitos fundamentais à vida, à liberdade, à saúde, ao trabalho, ao meio ambiente saudável e equilibrado, entre outros.

Quando se destaca a importância de discutir Direitos Humanos na escola, não se está sugerindo que seja criado um novo componente curricular para que sejam abordados os temas relacionados aos direitos humanos, o que seria um visão simplista e reducionista da questão, pois a simples criação da disciplina não resolveria. A disciplina em si seria relevante; entretanto, uma ação articulada nas escolas, entre todos os profissionais que compõem o corpo docente e técnico para incorporar a visão de cidadania do PNEDH, seria a gênese de um processo mais sólido de educação em direitos humanos. Faz-se necessário que a gestão escolar busque estratégias pedagógicas para que o tema seja discutido no meio escolar.

Talvez um caminho seja eleger anualmente eixos de atuação prioritários. A título de exemplo, a ecologia é um tema extremamente importante, fundante de outras questões, e, a partir dela, poder-se-ia tratar, por exemplo, a questão dos refugiados ambientais, ou seja, a violação dos direitos humanos das pessoas que fogem de suas nações por causa de desastres climáticos, Tsunamis, secas, falta de água, terremotos, desaparecimento de suas terras pelo aumento do nível do mar; isso tudo são efeitos vistos prioritariamente em camadas das populações mais vulneráveis do mundo. Daí, esse eixo poderia ser "explorado", "dissecado", por toda a escola, de forma integrada, com diversas ações desenvolvidas ao longo do ano.

\section{REFERÊNCIAS}

ABÍLIO, Francisco José Pegado; SATO Michèle (org.). Educação ambiental: do currículo da educação básica às vivências educativas no contexto do semiárido paraibano. João Pessoa: Editora Universitária da UFPB, 2012.

ARAÚJO, Ulisses F. A construção da cidadania e de relações democráticas no cotidiano escolar. In: ZENAIDE, M. de N. T. et al. Direitos Humanos: capacitação de educadores. João Pessoa: Editora Universitária; UFPB, 2008.

ARENDT, Hannah. Entre o passado e o futuro. In: ARENDT, Hannah. A crise na educação. Trad. Mauro W. Barbosa. 5. ed. São Paulo: Perspectiva, 1957-1979.

ARROYO, Miguel Gonzalez; FERNANDES Bernardo Mançano. A educação básica e o movimento social do campo. Brasília, DF: Articulação Nacional por uma Educação Básica do Campo, 1999. (Coleção por uma Educação Básica do Campo, $n^{\circ} 2$ ).

BARBOSA, Maria Simara Torres. A emancipação política do Brasil. In: BARBOSA, M. S. Torres. História da educação. São Luís: Ed. Uema Net, 2010.

BARREIRO, Guilherme Scodeler de Souza; FARIA, Guilherme Nacifde; SANTOS, RaíssaNaiady Vasconcelos. Educação em Direitos Humanos: uma tarefa possível e necessária. Educação em Perspectiva, Viçosa, v. 2, n. 1, p. 58-77, jan./jun. 2011.

BATISTA Jéssica Holanda de Medeiros et al. Políticas públicas e Educação em Direitos Humanos: o PNEDH e o caso brasileiro. 2015. Disponível em: https://dialnet.unirioja.es/descarga/articulo/5460340.pdf. Acesso em: 19 ago. 2016. 
BELLINHO, Lilith Abrantes. Uma evolução histórica dos Direitos Humanos. Curitiba, PR: Faculdades Integradas do Brasil - Unibrasil. 2012. Disponível em: http://www.unibrasil.com.br/arquivos/direito/20092/lilith-abrantes-bellinho.pdf. Acesso em: 21 ago. 2016.

BENEVIDES, Maria Victoria. Educação em Direitos Humanos: de que se trata? São Paulo: Faculdade de Educação da USP; Rede Brasileira de Educação em Direitos Humanos. 18/2/2000. Palestra de abertura do Seminário de Educação em Direitos Humanos. 2000. Disponível em: http://hottopos.com/convenit6/victoria.htm\#_ftn2. Acesso em: 22 jul. 2016.

BITTAR, Eduardo C. B. A escola como espaço de emancipação dos sujeitos. In: ZENAIDE, M. de N. T. et al. (org.). Direitos Humanos: capacitação de educadores. João Pessoa: Ed. Editora Universitária; UFPB, 2008. V. 2.

BOBBIO, Norberto. A era dos Direitos. 7. ed. Trad. Carlos Nelson Coutinho. Rio de Janeiro: Editora Elsevier, 2004. BRANDÃO, Elias Canuto. Violação do Direito à educação dos povos do campo. Belém. Disponível em: http:// www.canal6.com.br/x_sem2016/artigos/4A-04.pdf. Acesso em: 25 set. 2016.

BRASIL, Naira. 25 anos da Aids: desafios para o "tempo de direitos". In: BITTAR, Eduardo C. (org.). Direitos humanos no século XXI: cenários de tensão. 1. ed. Rio de Janeiro: Forense Universitária; São Paulo: ANDHEP; Brasília: Secretaria Especial dos Direitos Humanos, 2008.

BRASIL. Ministério da Educação. Secretaria de Educação Continuada, Alfabetização, Diversidade e Inclusão - Secadi. Educação do Campo: marcos normativos. Brasília: Secadi, 2012. Disponível em: http://www.planalto.gov. br/ccivil_03/_ato2007-2010/2010/decreto/d7352.htm. Acesso em: 30 mar. 2017.

BRASIL. Lei Darcy Ribeiro. LDB: Lei de Diretrizes e Bases da Educação Nacional: Lei no 9.394, de 20 de dezembro de 1996, que estabelece as diretrizes e bases da educação nacional [recurso eletrônico]. 8. ed. Brasília: Câmara dos Deputados, Edições Câmara, 2013a. Disponível em: http://www.planalto.gov.br/ccivil_03/leis//9394.htm.; http://bd.camara.leg.br. Acesso em: 30 mar. 2017.

BRASIL. Comitê Nacional de Educação em Direitos Humanos. Caderno de Educação em Direitos Humanos: Educação em Direitos Humanos: Diretrizes Nacionais: 2013. Brasília: Secretaria Especial dos Direitos Humanos, 2013b. BRASIL. Comitê Nacional de Educação em Direitos Humanos. Plano Nacional de Educação em Direitos Humanos: 2007. Brasília: Secretaria Especial dos Direitos Humanos, 2007.

BRASIL. Constituição da República Federativa do Brasil. Brasília, DF: Senado Federal; Centro Gráfico, 1988.

BRASIL. Constituição da República Federativa do Brasil: texto constitucional promulgado em 5 de outubro de 1988. Brasília: Senado Federal; Subsecretaria de Edições Técnicas, 2005. Disponível em: http://www.planalto. gov.br/ccivil_03/constituicao/constituicao.htm.; http://www.senado.gov.br/sf/legislacao/const/. Acesso em: 30 mar. 2017.

BRASIL. Secretaria de Educação Fundamental. Parâmetros Curriculares Nacionais: apresentação dos temas transversais, ética. Brasília: MEC; SEF, 1997, 146p.

CALDART, Roseli Salete. Por uma educação do campo: traços de uma identidade em construção. In: KOLLING, Edgar Jorge; CERIOLI, Paulo Ricardo; CALDART, Roseli Salete (org.). Educação do campo: identidade e políticas públicas. Brasília, DF: Articulação nacional por uma educação do campo, 2002. (Coleção por uma educação do campo, no 4).

CAMPOS, K. P. B.; NÁRIO, J. F. da S.; SOUZA, A. G. A inclusão educacional: limites e possibilidades. In: SILVA, J. I. A. O. et al. Cidadania, educação e direitos humanos no semiárido. Campina Grande: EDUFCG, 2012, p. 103-132.

CANDAU, Vera Maria Ferrão; SACAVINO, Susana Beatriz. Educação em direitos humanos e formação de educadores. Educação, Porto Alegre, impresso, v. 36, n. 1, p. 59-66, jan./abr. 2013.

CANDAU, Vera Maria. Educação e Direitos Humanos, currículo e estratégias pedagógicas. In: ZENAIDE, M. de N. T. et al. (org.). Direitos Humanos: capacitação de educadores. João Pessoa: Editora Universitária; UFPB, 2008. V. 1.

CANDAU, Vera Maria. Educação em direitos humanos: desafios para a formação de professores. Novamérica, $\mathrm{n}$. 78, p. 36-39, 1998.

CARBONARI, Paulo César. Educação em direitos humanos: esboço de reflexão conceitual. In: BITTAR, Eduardo C. (org.). Direitos humanos no século XXI: cenários de tensão. 1. ed. Rio de Janeiro: Forense Universitária; São Paulo: ANDHEP; Brasília: Secretaria Especial dos Direitos Humanos, 2008.

CAVALCANTE, Ludmila. Do rural ao campo - mudanças de paradigmas educacionais. Revista Marco Social, Rio de Janeiro, n. 12, 2010.

COMPARATO, Fábio Konder. A afirmação histórica dos direitos humanos. 7. ed. rev. e atual. São Paulo: Saraiva, 2010.

CONTAG. Confederação Nacional dos Trabalhadores da Agricultura. Educação do Campo: base para uma reflexão: In: CONTAG. Educação do campo semeando sonhos... cultivando direito. Brasília: Contag, 2010. 
CRETELLA JR., José. Comentários à Constituição Brasileira de 1988. Rio de Janeiro: Forense. v. 2., 2. ed. 1991 e v. 8, 2. ed. 1993.

DIAS, Adelaide Alves. A escola como espaço de socialização da cultura em direitos humanos. In: ZENAIDE, M. de N. T. et al. (org.). Direitos Humanos: capacitação de educadores. João Pessoa: Editora Universitária; UFPB, 2008. V. 2.

DIAS, Adelaide Alves. Da educação como direito humano aos direitos humanos como princípio educativo. In: SILVEIRA, Rosa Maria Godoy et al. (org.). Educação em Direitos Humanos: fundamentos teórico-metodológicos. João Pessoa: Editora Universitária, 2007.

EMERIQUE, Lilian Márcia Balmant; GUERRA, Sidney. A dignidade da pessoa humana e o direito ao mínimo vital. In: BITTAR, Eduardo C. (org.). Direitos humanos no século XXI: cenários de tensão. 1. ed. Rio de Janeiro: Forense Universitária; São Paulo: ANDHEP; Brasília: Secretaria Especial dos Direitos Humanos, 2008.

FONSECA, J. J. S. Metodologia da pesquisa científica. Fortaleza: UEC, 2002. (Apostila).

FREIRE, Paulo. Conscientização: teoria e prática da libertação. Uma introdução ao pensamento de Paulo Freire. Tradução Kátia de Mello e Silva. São Paulo: Moraes, 1980.

FREIRE, Paulo. Educação e mudança. 2. ed. São Paulo: Paz e Terra, 2011.

FREIRE, Paulo. Pedagogia da autonomia: saberes necessários à prática educativa. São Paulo: Paz e Terra, 2002. GERHARDT, T. E. et al. Estrutura do Projeto de Pesquisa. Métodos de pesquisa. Porto Alegre: Editora da UFRGS, 2009. p. 65-88.

GERHARDT, Tatiana Engel; SILVEIRA Denise Tolfo (org.). Métodos de pesquisa. Porto Alegre: Editora da UFRGS, 2009.

GIL, Antônio Carlos. Como elaborar projeto de pesquisas. 4. ed. São Paulo: Atlas, 2002.

GIL, Antonio Carlos. Métodos e técnicas de pesquisa social. 6. ed. São Paulo: Atlas, 2008.

GIL, Antonio Carlos. Métodos e técnicas de pesquisa social. 6. ed. São Paulo: Atlas, 2010.

GOHN, Maria da Glória. Direitos Humanos em seus desafios contemporâneos. In: GOHN, Maria da Glória. Movimentos sociais e cidadania. Rio de Janeiro: Ed. PUC-Rio; Pallas, 2012.

IHERING, Rudolf von. A luta pelo direito. São Paulo: Martin Claret, 2005. p. 27.

LAFER, Celso. A reconstrução dos direitos humanos - um diálogo com o pensamento de Hannah Arendt. São Paulo: Companhia das Letras, 1998.

LARAIA, Roque de Barros. Cultura: um conceito antropológico. 17. ed. Rio de Janeiro. Editora Jorge Zahar, 2004. LEITE, Talita Soares. Direitos humanos e educação pública: uma leitura crítica acerca da educação em direitos humanos. 2011. Disponível em: http://www.uel.br/projetos/lenpes/pages/arquivos/aLEITE\%20Talita.pdf. Acesso em: 19 ago. 2016.

LOCKS, Geraldo Augusto; GRAUPE, Mareli Eliane; PEREIRA, Jisilaine Antunes. Educação do campo e direitos humanos: uma conquista, muitos desafios. Conjectura: Filos. Educ., Caxias do Sul, v. 20, n. especial, p. 131-154, 2015.

LUNAS, Alexandra da Costa; ROCHA, Eliene Novaes. Práticas pedagógicas e formação de educadores (as) do campo: caderno pedagógico da educação do campo. Organização Alexandra da Costa Lunas e Eliene Novaes Rocha. Brasília: Dupligráfica, 2009.

MARCONI, Marina de Andrade; LAKATOS, Eva Maria. Metodologia científica. 5. ed. São Paulo: Atlas, 2009.

MENDONÇA, Pedro Furtado. O Direito à Educação e os Direitos Humanos conexos - indivisibilidade, interdependência \& justiciabilidade. Disponível em: http://www.direitonet.com.br/artigos/exibir/6415/O-Direito-a-Educacao-e-os-Direitos-Humanos-conexos-Indivisibilidade-interdependencia-justiciabilidade. Acesso em: 20 ago. 2016.

MINAYO, Maria Cecília de Souza (org.). Pesquisa social: teoria, método e criatividade. 28. ed. Petrópolis, RJ: Vozes, 2009.

NETO, José Francisco de Melo. Metodologias participativas em educação para os Direitos Humanos. In: ZENAIDE, M. de N. T. et al. (Org.). Direitos Humanos: capacitação de educadores. João Pessoa: Editora Universitária; UFPB, 2008. V.1.

NEVES, José Luís. Pesquisa qualitativa - características, usos e possibilidades. Revista Caderno de Pesquisas em Administração, São Paulo, v. 1, n. 3, p. 1-5, 2o sem. 1996.

OLIVEIRA, Ivanide Apoluceno de. Filosofia da educação: reflexões e debates. Petrópolis, RJ: Vozes, 2006.

OLIVEIRA, Romualdo Portela de. O Direito à Educação na Constituição Federal de 1988 e seu restabelecimento pelo sistema de Justiça. Revista Brasileira de Educação, n. 11, p. 61-74, maio/jun./jul./ago. 1999. 
ONU. Organização das Nações Unidas. Plano de ação: Programa Mundial para Educação em Direitos Humanos. Nova York; Genebra: Unesco, 2006.

ONU. Organização das Nações Unidas. Declaração Universal dos Direitos Humanos. 1948.

ORTEGA, Antonio César. Cidades imaginárias. O Brasil é menos urbano do que se calcula. Revista Estudos Sociedade e Agricultura, Campinas, p. 185-190, 18 abr. 2002.

PEQUENO, Marcone. O fundamento dos direitos humanos. In: ZENAIDE, M. de N. T. et al. (org.). Direitos Humanos: capacitação de educadores. João Pessoa: Editora Universitária; UFPB, 2008a. V. 1.

PEQUENO, Marcone. O sujeito dos Direitos Humanos. In: ZENAIDE, M. de N. T. et al. (Org.). Direitos Humanos: capacitação de educadores. João Pessoa: Editora Universitária; UFPB, 2008b. V. 1.

PEREZ, Luís Aguirre. Educación para los derechos humanos. El gran desafío contemporáneo. In: Paz y Justicia, Montevideo: Serpaj, n. 8, oct./dic. 1986.

PIOVESAN, Flávia. Ações afirmativas da perspectiva dos Direitos Humanos. Cadernos de Pesquisa, v. 35, n. 124, p. 43-55, jan./abr. 2005.

PIOVESAN, Flávia. Direitos Humanos: desafios e perspectivas contemporâneas. Rev. TST, Brasília, v. 75, n. 1, p. 107-113, jan./mar. 2009.

PIOVESAN, Flávia. Temas de direitos humanos. 5. ed. São Paulo: Saraiva, 2012.

PIRES, Angela Maria Monteiro da Motta. A educação do campo como direito a uma escola pública de qualidade. 2012. Disponível em: http://www.anpae.org.br/congressos_antigos/simposio2009/38.pdf. Acesso em: 10 out. 2016.

PORTELA, Paulo Henrique Gonçalves. Direito Internacional Público e Privado. 3. ed. Salvador: Juspodvm, 2011.

POZO, J. I. Aprendizes e mestres: a nova cultura da aprendizagem. Porto Alegre: Artmed, 2002.

RABENHORST, Eduardo R. O que são Direitos Humanos? In: ZENAIDE, M. de N. T. et al. (org.). Direitos Humanos: capacitação de educadores. João Pessoa: Ed. Editora Universitária; UFPB, 2008. V. 1.

RICHARDSON, R. J. Pesquisa social: métodos e técnicas. São Paulo: Atlas, 2009.

RODRIGUES, Aparecida Salustiano. Educação ambiental no contexto do ensino da geografia no cariri paraibano. 2015. Monografia (Educação do Campo) - Universidade Federal de Campina

Grande, Sumé, PB, 2015.

SACAVINO, Susana. Direito humano à educação no Brasil: uma conquista para todos/as? In: GODOY, Silveira Rosa Maria et al. Educação em Direitos Humanos: fundamentos teórico-metodológicos. João Pessoa: Editora Universitária, 2007. 513p.

SACAVINO, Susana. Formação de educadores/as em/para os Direitos Humanos: um horizonte de sentido - uma maneira de fazer - uma forma de ser. In: ZENAIDE, M. de N. T. et al. (org.). Direitos Humanos: capacitação de educadores. João Pessoa: Ed. Editora Universitária; UFPB, 2008. V. 1.

SADER, Emir. Contexto histórico e educação em direitos humanos no Brasil: da ditadura à atualidade. In: SILVEIRA, Rosa Maria Godoy et al. (org.). Educação em direitos humanos: fundamentos teórico-metodológicos. João Pessoa: Editora Universitária, 2007.

SAVIANI, Dermeval. A educação na Constituição Federal de 1988: avanços no texto e sua neutralização no contexto dos 25 anos de vigência. RBPAE, v. 29, n. 2, p. 207-221, maio/ago. 2013.

SCHULER, Fernanda Rangel. A formação para os direitos humanos: uma nova perspectiva para o ensino jurídico? In: BITTAR, Eduardo C. (org.). Direitos humanos no século XXI: cenários de tensão. 1. ed. Rio de Janeiro: Forense Universitária; São Paulo: ANDHEP; Brasília: Secretaria Especial dos Direitos Humanos, 2008.

SERRA, Erica Roberts C. Igualdade e diferença nos direitos humanos. In: BITTAR, Eduardo C. (org.). Direitos humanos no século XXI: cenários de tensão. 1. ed. Rio de Janeiro: Forense Universitária; São Paulo: ANDHEP; Brasília: Secretaria Especial dos Direitos Humanos, 2008.

SILVA, Aida Maria Monteiro; TAVARES, Celma. Educação em Direitos Humanos no Brasil: contexto, processo de desenvolvimento, conquistas e limites. Revista Educação, v. 36, n. 1, p. 50-58, jan./abr. 2013.

SILVA, Denise Carvalho da. Indivisibilidade entre os direitos civis e políticos e os direitos econômicos, sociais e culturais: problemas de reconhecimento e dificuldades na implementação. In: BITTAR, Eduardo C. (org.). Direitos humanos no século XXI: cenários de tensão. 1. ed. Rio de Janeiro: Forense Universitária; São Paulo: ANDHEP; Brasília: Secretaria Especial dos Direitos Humanos, 2008.

SILVA, J. I. A. O.; BRITO, P. S.; RODRIGUES, A. S. Educação e Direitos Humanos: o caso do Centro de Desenvolvimento Sustentável do Semiárido. Cidadania, Educação e Direitos Humanos no Semiárido. In: SILVA, J. I. A. O. et al. Cidadania, educação e Direitos Humanos no semiárido. Campina Grande: EDUFCG, 2012. p. 19-48. 
SILVA, Maria do Socorro. Educação como direito: reler o passado, refletir o presente e planeja o futuro. In: LUNAS, A. C.; ROCHA, E. N. (org.). Práticas pedagógica e formação de educadores(as) do campo. Brasília: Dupligráfica, 2009.

TONET, Ivo. Para além dos Direitos Humanos. Revista Novos Rumos, ano 17, n. 37, p. 63-72, 2002.

VEIGA, José Eli da. Nem tudo é urbano. Cidades/Artigos. Argumentos desenvolvidos em 30 artigos publicados no jornal Valor, em 2003 e na obra Cidades Imaginárias: O Brasil é menos urbano do que se calcula. Campinas, SP: Editora Autores Associados, 2002. Disponível em: http://cienciaecultura.bvs.br/pdf/cic/v56n2/a16v56n2.pdf. Acesso em: 21 out. 2016.

YIN, R. K. Case study research: design and methods. London: Sage, 1984

YIN, Roberto K. Estudo de caso: planejamento e métodos. 2. ed. Porto Alegre: Editora Bookmam. 2001.

ZLUHAN, Mara Regina; RAITZ, Tânia Regina. A educação em direitos humanos para amenizar os conflitos no cotidiano das escolas. Rev. Bras. Estud. Pedagog. (on-line), Brasília, v. 95, n. 239, p. 31-54, jan./abr. 2014. 